\title{
Analysis of China's legislation on soil contamination in the light of the realization of an ecological civilization
}

\author{
Poderati, G., ${ }^{1}$ \\ ${ }^{1}$ Research Institute of Environmental Lawscola, Wuhan University, Wuhan 430072, Hubei Province, China. \\ Corresponding author: Giuseppe Poderati,Ph.D. Candidate, email: gpoderati@gmail.com
}

\begin{abstract}
After several years of population growth, urbanization, rapid economic and growing depletion of natural resources, China's environmental related challenges are nearing a tipping point. Following the ideal of creating an ecological civilization 生态文明, China is on its way to greening socio-economic development. In fact, the ecological civilization is the primary conceptual key used by the People's Republic of China capable of providing a coherent framework for adjustments to socioeconomic development in the $21^{\text {st }}$ century to allow people to live in health within the eco-environmental boundaries of the Earth during the current geological era of the Anthropocene. After delineating the features of the ecological civilization, this paper aims to analyze the legal regime of contaminated lands in China as outlined by the 2018 Soil Contamination Law in the light of making a stable and prosperous ecological civilization. Besides that, this paper examines the statutory definition of soil contamination under the law describing the environmental legislative frameworks.
\end{abstract}

Keywords - China, socio-economic development, ecological civilization, soil contamination law

Received: January 1, 2022.

Accepted: January 19, 2022

\section{INTRODUCTION}

China has achieved an impressive economic success and increased its comprehensive strength as a result of its reform and opening to the rest of the world, thereby improving its standing in the international community. Nevertheless, after

\footnotetext{
1 "The concept of ecological civilization spreads in the Soviet Union in the late 1960s thanks to groups of scientists who identify the link between industrial modernization and the emergence of internal environmental crises as a problem of civilization in general, which can only be solved by launching of an ecological revolution" see, Bellamy Foster, J., "The Earth-System Crisis and Ecological Civilization: a Marxian View", International Critical Thought 7, 4, 2017, 449.
}

several years of population growth, urbanization, rapid economic and growing depletion of natural resources, China's environmental related challenges are nearing a tipping point. Following the ideal of creating an Ecological Civilization $^{1}$ (EC - shengtai wenming 生态文明 ${ }^{2}$ ), China is

\footnotetext{
2 The introduction of the term shengtai wenming in the title of an article by Qiushi dates back to December 2007, two months after the introduction of the term by $\mathrm{Hu}$ Jintao in the report to the 17th Congress of the CCP. See, Zhong Folin 钟 佛霖 and Peng Daobin 彭道宾, “Chuangjian lüse changye kaifaqu, wei wo sheng jingji de chixu fazhan kaibi xinlu” 创 建绿色产业开发区 - 为我省经济的持续发展开辟新路
} 
on its way to systematically green socio-economic development. In point of fact, the ecological civilization is the primary conceptual key used by the People's Republic of China capable of providing a coherent framework for adjustments to socio-economic development in the $21^{\text {st }}$ century to allow its people to live in health within the ecoenvironmental boundaries of the Earth during the current geological era of the Anthropocene. ${ }^{3}$ With these remarks in mind, this paper delineates the features of the EC. Afterward, this paper aims to analyze the legal regime of contaminated soils in China as outlined by the 2018 Soil Contamination Law in the light of making a stable and prosperous ecological civilization. Besides that, it examines the statutory definition of soil contamination under the law. It describes the environmental legislative frameworks that addresses the soil contamination issue in China, identifying aspects of risk management and control, remediation of contaminated soil, liability issues and financial mechanisms according to the law.

\section{GENERAL ASPECTS OF THE ECOLOGICAL Civilization}

China desires to synchronize its economic growth with the environmental protection. A holistic approach is adopted to develop the society in a sustainable way by using as a guiding concept the so-called EC.

Chronologically speaking, to see the concept of EC with its set of general principles introduced in the official speeches of the Communist Party of China (CCP), it is necessary to wait for the former President Hu Jintao's Report to the $17^{\text {th }}$ Party Congress in 2007. This report addresses the theme of the "construction of an EC" defining it as: "an industrial model of growth and consumption based on energy saving of resources and environmental protection" for the programmatic realization of a "moderately prosperous society". 4 The EC is a "steering" work of the central government. And yet, it has been defined as a State-initiated imaginary concept of our global future. ${ }^{5}$

(Create green industrial development areas for the opening of new sustainable development paths for the economy of our province), Qiushi 求实, 11, 1997, 36-38.

3 Hanson, A. 'Ecological Civilization in the People's Republic of China: Values, Action, and Future', ADB 2019.

4 “Hu Jintao zai dang de shiqida shang de baogao" 胡锦涛在 党的十七大上的报告 (Report by Hu Jintao to the 17th Party Congress), 25 October 2007. Fourth Section entitled: "Shixian quanmian jianshe xiaokang shehui fendou mubiao de xin yaoqiu” 实现全面建设小康社会奋斗目标的新要求 (The new requirements for the achievement of the goals for building a moderately prosperous society).

${ }^{5}$ Hansen, M., Li, H. and Svarverud, R., 2018. Ecological civilization: Interpreting the Chinese past, projecting the global future. Global Environmental Change, 53, pp.195203.
Figure 1. Environmental Kuznets curve ${ }^{6}$ is one of the best tools to understand and visualize the current relation between the per capita income generated by the rapid economic development and the environmental degradation. ${ }^{7}$ Source: Panayotou, T., 1979.

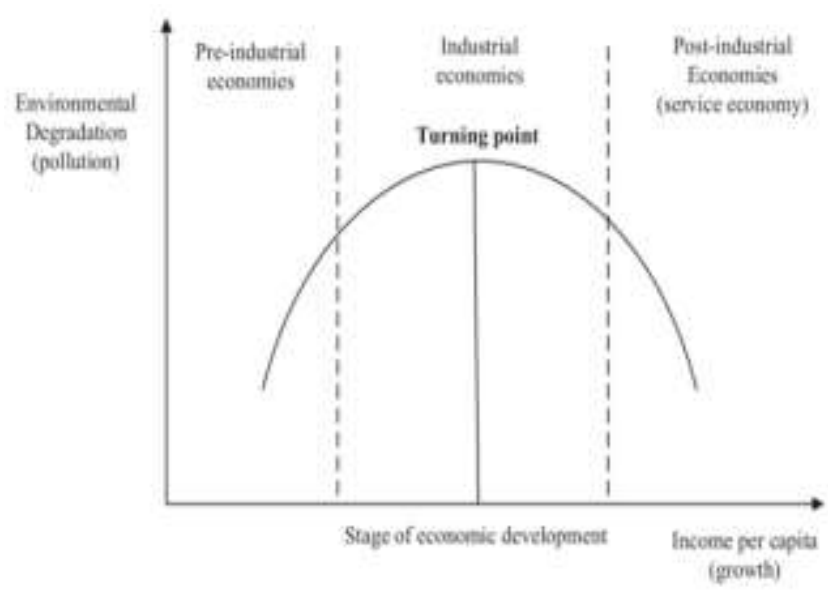

In 2012, President Xi Jinping incorporated the term under discussion in the CCP statute, elevating it to the theoretical level of a constituent element of "Xi Jinping's Thought on Socialism with Chinese Characteristics for a New Era"8 and incorporating it into the so-called "five-in-one" (wu wei yi ti 五位 一体), or in the overall development strategy of the “five constructions" (wu ge jianshe 五个建设) that includes accurately: the economy, politics, culture, society and ecology. Subsequently, the fact that EC, in 2018, was crystallized in the People's Republic of China's Constitution is particularly noteworthy in our present context. This, in point of fact, legitimated the most recent Chinese Government' key climate policies, such as:

1. $\mathrm{Xi}$ Jinping announced in September 2020 that emissions would peak in 2030 and be carbon neutral by 2060 . In December 2020, he clarified his 2030 commitments

6 Panayotou, T., 1979. Economic Growth and the Environment. In: Spring Seminar of the united Nations Economic Commission For Europe. Cambridge, MA, USA: Harvard University and Cyprus International Institute of management, Massachusetts hall Cambridge.

7 Özcan, B. and Ozturk, I., 2019. Environmental Kuznets curve (EKC). 1st ed.

${ }^{8} \mathrm{Xi}$ Jinping, "Juesheng quanmian jiancheng xiaokang shehui duoqu xin shidai zhongguo tese shehuizhuyi weida shengli" 决胜全面建成小康社会夺取新时代中国特色社会主义大

胜利 (Securing a decisive victory in building a moderately prosperous society comprehensively and committing to the great success of socialism with Chinese characteristics for a new era), Sections 1 and 3. 
(carbon intensity, non-fossil energy share, forest stock, and wind and solar installed capacity).

2. Its 14th Five Year Plan (2021-25) set interim targets for energy and carbon intensity, as well as non-fossil energy share. The 14th Five-Year Plan period [2021-25] and the 15th Five-Year Plan period [2026-30] are both aimed at limiting coal usage.

3. According to Xi Jinping, China "would not build new coal-fired power projects abroad."

4. Preparing for COP26, China produced two highlevel documents: a working guidance paper on the 2030 peaking target and an action plan for the 2030 peaking goal. These are the first phases in China's " $1+\mathrm{N}$ " climate change initiative. China presented a long-term development strategy at COP26, as required by Article 4 (19) of the Paris Accord.

The elaboration of the concept under parlance allows Beijing - with its traditional culture - to demonstrate that China has historically given importance to environmental protection and climate safety. The "construction of an EC" is thus recognized as a non-secondary component of the development model from which Beijing aims to create shared and common prosperity via the New Silk Road. If the New Silk Road, in fact, aims to demonstrate in the long term the success of commercial, industrial, and investment policies and strategies that have marked the Chinese economic development, the concept of the EC aims to demonstrate inter alia the evolution of the environmentalism that has spread since the Rio de Janeiro Earth Summit 1992 and the rejection of the irresponsible Western industrial civilization. Here it is important to highlight the opinion of a prominent scholar, namely Pan Yue: "According to Western traditional philosophy, mankind is the most valuable part of the world while nature and other forms of life are targets for our domination and therefore have no value. Therefore, morality is only designed for man and there is no need to act morally towards nature or any other forms of life. This is the philosophical basis for the concept of man ruling nature in the industrial civilization. The ecological civilization, however, believes that value exists in both man and nature; nature is also endowed with the power to take the initiative; and all forms of life depend on nature, including mankind. Therefore, man must respect life and nature, as the Earth is home to both". 9 Thus characterized, humans and nature both have importance in the ecological civilization. Nature has the capacity to initiate, and all forms of life, including humans,

\footnotetext{
${ }^{9}$ See supra note 7, p. 198.

${ }^{10}$ Li Ganjie 李干杰, “Shenru Guanche Xi Jinping shengtai wenming sixiang yi shengtai huanjing baohu youdao chengji yingjie xin Zhongguo chengli 70 zhou nian” 深入贯彻习近 平生态文明思想 以生态环境保护优异成绩迎接新中国成 立 70 周年 (Fully implement Xi Jinping's thinking on ecological civilization, welcome the 70th anniversary of New China based on the excellent achievements in terms of environmental protection), China Environment News 中国环
}

are dependent on nature. As such, man must respect life and environment on Earth.

EC is part of the so called "Chinese dream", and it is not surprising how the ruling party defines it as a "strategy" (zhanlüe 战略) and not a "policy" (zhengce 政策) or a “measure" (cuoshi 措施). "Zhanlüe" is a term that helps the CCP to emphasize its attempt and that of the entire Chinese ruling class to devote themselves fully to the pursuance of forward-looking environmental sustainability policies. Hence, the construction of an EC would coincide with the introduction of a new model of modernization capable of favoring the "harmonious development between Man and Nature" (ren yu ziran [de] hexie fazhan 人与 自然 [的] 和谐 发展). The “Thinking of Xi Jinping on EC” (Xi Jinping shengtai wenming sixiang 习近平 生态 文明 思想 ${ }^{10}$ ), a new theorem of environmental sustainability with Chinese characteristics not only based on the introduction of new laws, the construction of systems for the training of cadres, or the introduction of adequate emission trading systems but also on the deeper study of ecology, and the environmental protection at large.

Besides that, it is important to recall once again Pan's thinking according to which human matters must be conducted in accordance with the will of nature. It is only when humans adopt the laws of Nature and translate them into human norms, and when they follow the principles of Nature, that a wealthy state can be established, and a peaceful society can be established. ${ }^{11}$

This led several scholars ${ }^{12}$ to identify six main EC principles, namely: (i) 'Harmony between Man and Nature'; (ii) Adoption of strictest regulations and laws; (iii) Joint efforts from the international community are towards safeguarding EC; (iv) 'Lucid waters and lush mountains are invaluable assets' (development principle); (v) 'no welfare more universally beneficial than a sound natural environment' (awareness and action principle); (vi) 'mountains, rivers, forests, fields, lakes and grasslands form a biotic community' (governance principle). The relationship between six principles of EC and UN Sustainable Development Goals (SDGs) is quite evident. It is worth noting that the doctrine recognized that the $\mathrm{EC}$ aspires to complement the three main

\footnotetext{
${ }^{11}$ See supra note 7, p. 200.

${ }^{12}$ Among the scientific and government institutions that work on the EC concept development and implementation: Central Academy of Socialism in Beijing, China's State Environmental Protection Agency, Ministry of Ecology and Environment of the People's Republic of China, Asian Development Bank, Institute for Ecological Civilization, Research Institute of Environmental Law at Wuhan University, Institute of Ecology at Zhejiang University, Law Schools of Tsinghua University, and Xiamen University.
}

境报, 28 January 2019. 
components of sustainable development, namely the environmental, economic, and social ones. ${ }^{13}$

Figure 3. The relationship between six principles of EC and UN (SDGs). ${ }^{14}$ Core concept.

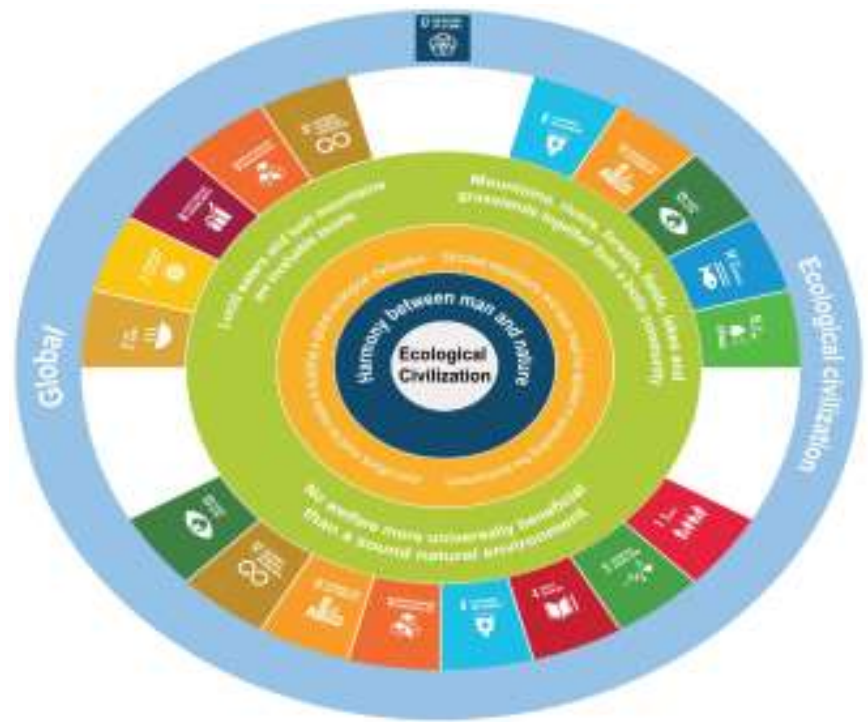

Source: Wei, F., et al. (2020). "Ecological civilization: China's effort to build a shared future for all life on Earth." National Science Review 8(7). Oxford University Press.

However, in contrast to the SDGs, there is a greater focus placed on political and cultural factors, as well as on the establishment of a new connection between mankind and nature. In any case, China's experiences can serve as a spark for a worldwide discussion about how to best achieve the SDGs and the goal of living in harmony with environment in a way that is appropriate for each country's unique

${ }^{13}$ Kuhn, B., 2019. Ecological Civilisation in China. Dialogue of Civilizations Research Institute, p.1.

${ }^{14}$ Wei, F., et al. (2020). "Ecological civilization: China's effort to build a shared future for all life on Earth." National Science Review 8(7). Oxford University Press.

15 Xie, M., Duan, H., Kang, P., Qiao, Q. and Bai, L., 2021. Toward an Ecological Civilization: China's Progress as Documented by the Second National General Survey of Pollution Sources. Engineering,.

16 Development Research Center of the, T., 2014. China's Urbanization and Land:: A Framework for Reform. Urban China: Toward Efficient, Inclusive, and Sustainable Urbanization, pp.263-336.

17 Wang, M. and Wei, D., 2022. Population and Natural Resources case study: What are the challenges of meeting the resource needs of a very large population?. [online] AAG Center for Global Geography Education. Available at: http://cgge.aag.org/PopulationandNaturalResources1e/CS_C hina_July09CS_China July09 print.html [Accessed 19 January 2022].

${ }^{18}$ Liu, S., Chen, Q., Quan, P., Zhang, M., Zhang, S., Guo, L., Sun, X. and Wang, C., 2016. Cancer incidence and mortality circumstances. ${ }^{15}$ Globally, the COVID-19 epidemic has exposed how closely humans is bound to the natural world and how re-establishing a more harmonious relationship with nature is crucial to human survival. The concept and practices of EC in China provide crucial insights for the international community as it faces unprecedented difficulties. The next section analyses the legal implications of the EC, particularly in the field of soil protection.

\section{The Government's Legal AND Political RESPONSE TO THE ISSUE OF CONTAMINATED SOILS}

China's economy has risen fast since 1978, when economic reforms began. Industrialization, urbanization, and pollution came from rapid growth. ${ }^{16}$ Large quantities of waste gas, wastewater, and waste solids have been released into the environment, causing major pollution and ecosystem degradation. ${ }^{17}$ Sadly, both the government and the people have tolerated soil contamination, which has negatively impacted people's health and China's sustainable growth. The pollution level is really high. A variety of severe health problems associated with soil contamination, including brain damage and cancer, have contributed to China's high death rate. For instance, in Henan province, one of the primary grain producing areas in interior China, a high number of new cancer cases are identified each year. ${ }^{18}$ Soil contamination affects both urban and rural areas in China. ${ }^{19}$ Agricultural pesticides and fertilizers ${ }^{20}$ are major contributors to soil contamination in rural areas. Water contamination is a major issue in rural regions due to lack of adequate drinking water. In cities, individuals are harmed by soil contamination largely through air deposition and food. ${ }^{21}$ It is critical to identify harmful and hazardous substances (HHS) in soil too. One ought to note that the FAO lex database shows that the latest

in Henan province, 2012. Chinese Journal of Cancer Research, 28(3), pp.275-285.

${ }^{19}$ It is worth noting that the terms land and soil have two different meanings: "Land, then, is not merely soil; it is a fountain of energy flowing through a circuit of soils, plants, and animals. Food chains are the living channels which conduct energy upward; death and decay return it to the soil. The circuit is not closed; some energy is dissipated in decay, some is added by absorption from the air, some is stored in soils, peats, and long-lived forests; but it is a sustained circuit, like a slowly augmented revolving fund of life", see, Leopold, A., A Sand County almanac, and Sketches here and there, New York, Oxford University Press, 1949, p. 216.

${ }^{20}$ Fao.org. 2018. Background|Global Symposium on Soil Pollution | Food and Agriculture Organization of the United Nations. [online] Available at:

https://www.fao.org/about/meetings/global-symposium-onsoil-pollution/background/en/ [Accessed 19 January 2022]. 21 "China only has 0.21 hectares of agricultural land per person, about half of the world's average, but more than $40 \%$ of China's arable land is degraded" Delang, C., 2018. The consequences of soil degradation in China: a review. GeoScape, 12(2), pp.92-103. 
update on HHS list and limit values for soil concentration was in $1995 .^{22}$

Thus considered, throughout China's industrialization, soil contamination has been an ignored environmental issue. As a result of a scattering of provisions in various laws and regulations, soil pollution was previously left unaddressed, resulting in a legal vacuum and significant ambiguity for firms dealing with potential soil contamination issues. Indeed, the new law provides government departments, organizations and individuals with much-needed direction and systematic mechanisms for investigating, preventing, and cleaning up soil pollution, all of which are desperately needed.

Soil Contamination Law 2018 is the Government response. This law was unanimously adopted by the Standing Committee of the PRC National People's Congress on August $31^{\text {st }} 2018$, and entered into effect on January $1^{\text {st }}$, $2019 .{ }^{23}$ This is the first national law in China dealing solely with soil contamination risk management and remediation. The Soil Contamination Law and its administrative decrees set out procedures for identifying, recording, managing, and remediating polluted soil. It is a historic milestone. EC is its major ideological reference framework since soil is an indispensable asset for human development. This law was made with the political intent of inter alia achieving ecological progress in compliance with the six principle of EC and creating the conditions for sustainable development to flourish nationwide. Since 2012, the construction of ecological civilization, a concept aimed at promoting green development, has gained momentum as Xi's ideal of "lucid water and lush mountains are invaluable assets" has taken root throughout the country. This theoretical assertion fits "extremely well" with the concept of ecosystem protection, rehabilitation of degraded soil to benefit livelihoods and the environment, and overall land degradation neutrality. ${ }^{24}$

Through this law the contaminated soil legal regime's primary purpose is to address the control and disposal of

\footnotetext{
${ }^{22}$ Fao.org. 1995. FAO.org: . [online] Available at:

https://www.fao.org/faolex/results/details/en/c/LEXFAOC025129/ [Accessed 19 January 2022].

23 中华人民共和国土壤污染防治法 Law of the People's

Republic of China on the Prevention and Control of Soil Contamination 2018] (People's Republic of China), Standing Committee of the National People's Congress, Order No 8, 31 August 2018.

24 "On June 17, the $26^{\text {th }}$ World's Desertification and Drought Day, The CAS "Big Earth Data Science Engineering" Program (CASEarth) released their research results of using big Earth data in support of land degradation neutrality assessment along Belt and Road Region. The report shows that China has achieved land degradation neutrality in advance, and the net land restoration area accounts for $18.24 \%$ of the world's total, ranking first in the world, and contributing greatly to global land degradation neutrality"
}

historic soil pollution while also preventing and deterring future soil contamination in adherence to the main current principles and norms of international environmental law and policy. Basically, this law is able to create obligations (e.g., to protect soil and to prevent soil contamination) and liabilities for land use rights holders and administrative authorities in China.

It is vital that the expression "soil pollution" is defined appropriately under national legislation. The definition of soil contamination has a direct impact on how soil is classified as contaminated or uncontaminated, as well as how contaminated soil is distinguished from uncontaminated soil. ${ }^{25}$ Meanwhile, the definition enables environmental regulators and courts to determine the precise extent of contaminated soil, responsible parties, and their respective liabilities. The expression "soil contamination" is defined under Article 2 of the 2018 Soil Contamination Law. It states as follows: "For the purposes of this law, soil contamination means a phenomenon that certain substance is caused to enter soil on the surface of earth by human, resulting in the change in the chemical, physical, biological and other characters of soil, affecting the functions and effective utilization of soil, causing hazards to human health or damaging the ecology and environment". 26

China's polluted soil regime incorporates the concept of institutional controls. Numerous key mechanisms have been established in the 2018 Soil Contamination Law to guide the behavior of governments and environmental bodies. ${ }^{27}$ The law requires governments and environmental authorities at all levels to develop soil contamination control plans; develop a system of soil environmental standards; develop zoning restrictions based on the results of risk assessments; conduct investigation and monitoring; and collect and disclose soil contamination information.

Land use right holders, enterprises, public institutions, and other producers and business operators must take effective efforts to prevent and mitigate soil contamination and bear

Aerospace Information research Institute Chinese Academy of Sciences, 2021. China Realizes Land Degradation Neutrality-- [online] English.aircas.ac.cn. Available at:

http://english.aircas.ac.cn/ne/focus/202006/t20200619 2390 38.html [Accessed 8 October 2021].

${ }^{25}$ Fao.org. 2022. details $\mid$ FAO SOILS PORTAL | Food and Agriculture Organization of the United Nations. [online] Available at:

https://www.fao.org/soils-portal/soilex/countryprofiles/details/en/?iso3=CHN\&tx dynafef search=1\&rec uid=\&submit=Submit\& form build id=form13c18be57f332a3d1530f961c5165233964b95e0df474b0fa8 2c90b9c8b2eaab [Accessed 19 January 2022].

${ }^{26}$ Article 2 of the 2018 Soil Contamination Law.

27 MEE (2018). Handbook for interpretation and Implementation of the Law of the People's Republic of China on the Prevention and Control of Soil Contamination. Beijing: Law press China. 
legal responsibility for any soil contamination caused by their activities. Besides that, according to Article 5 Local people's governments at all levels must be accountable for preventing and controlling soil contamination and ensuring the safe use of soil within their administrative regions. ${ }^{28}$ This has to be interpreted in connection to Article 85 that plainly states: "Where the local people's governments at all levels, or their departments of ecology and environment or other departments responsible for supervision and administration of soil contamination prevention and control fail to perform their obligations specified in this Law, the persons directly in charge and the other directly responsible persons shall be subject to administrative punishments according to law". ${ }^{29}$ The Department of Ecology and Environment under the State Council has a pivotal role. ${ }^{30}$ To facilitate dynamic data updates and information exchange, the department established a soil environment fundamental database and a national soil environment information platform. It supports the scientific research, international exchanges and cooperation in the prevention and control of soil contamination (Articles 8-9). ${ }^{31}$ The department develops national risk control standards for soil contamination based on the land use purpose and works to strengthen efforts to establish a system of soil contamination prevention and control standards (Article 12). The department has the authority to conduct on-site inspections and sampling on the premises of enterprises, public institutions, and any other producers or business operators who may be responsible for soil contamination, and to require those inspected to provide pertinent materials and explain the issues. ${ }^{32}$

The department of ecology and environment under the State Council together with the departments of agriculture and rural affairs conduct several key monitoring activities on both agricultural and construction land with the due differences to keep a high level of safe and proper utilization of soil resources. To this purpose, the environmental impact assessment (EIA) is a necessary tool for prevention of pollution and protection of soil. In accordance with Article 22 "any enterprise or public institution wishing to dismantle facilities, equipment, buildings or structures shall take corresponding measures to prevent and control soil contamination". ${ }^{33}$ EIA is able to facilitate: (1) the control over the release of toxic and hazardous substances, and report the release information to the competent department of ecology and environment on an annual basis; (2) the establishment of an identification system for potential soil contamination to ensure continuous and effective prevention of leakage, runoff, spills or spreading of toxic and hazardous substances; and (3) the formulation and implementation of selfmonitoring plans, and report the monitoring data to the competent department of ecology and environment.

\footnotetext{
${ }^{28}$ Article 5 of the 2018 Soil Contamination Law.

${ }^{29}$ Article 85 of the 2018 Soil Contamination Law.

30 See, English.mee.gov.cn. 2022. Full text: Kunming Declaration. [online] Available at:

https://english.mee.gov.cn/News_service/news_release/2021

10/t20211015 956693.shtml [Accessed 19 January 2022].
}

The law contemplates at Article 45 that "the person liable for soil contamination is obligated to carry out risk control and remediation of soil contamination. Where the person liable for soil contamination cannot be identified, the land use right holder shall carry out risk control and remediation of soil contamination". ${ }^{34}$ Notably, the Soil Pollution Prevention Law does not define "Responsible Person" expressly. According to China's 2016 Soil Action Plan, the Responsible Person appears to be the one who creates the soil contamination, as well as any successors.

The law in China imposes requirements on businesses. Manufacturing and operating enterprises, as well as landowners, must take appropriate efforts to avoid and decrease soil contamination. If a study, monitoring, or inspection reveals potential soil pollution on construction land, the land use right holder must investigate. If the inquiry reveals pollution in excess of applicable limits, the polluter and the landowner must prepare and file a risk assessment report. The authorities may include the plot in a list of construction land susceptible to soil pollution risk management, control, and restoration based on their analysis of the risk assessment report. To restore polluted groundwater, the polluter must establish a restoration strategy that includes prevention and cleanup. After that, the polluter must hire a third party to assess the success of its risk management, control, and restoration efforts. Moreover, polluting companies will be recognized as organizations subject to extensive supervision by the government and will be required to conduct advanced soil contamination assessments whenever land utilized for production changes or is transferred.

\section{CONCLUSION}

To conclude with, the Soil Contamination Law 2018 may encourage all Chinese parties to act against soil contamination. It enables the Chinese authorities to systematically rehabilitate damaged land and regulate soil pollution activities. The law, along with the implementation of legally binding and enforceable rules and regulations, will support investors and businesses. Meanwhile, it establishes new obligations and potential liabilities that can raise expenses for certain corporate activities in China. As mentioned above, the elaboration of the 2018 Soil Contamination Law is a significant milestone. However, due to the broad scope of the law, environmental authorities are assigned authority over a number of concerns, including appropriate environmental standards, specific mechanisms for allocating liabilities, utilizing funds, and other economic incentives. In these areas, regulations and administrative decrees are expected to be implemented in the near future. As

\footnotetext{
${ }^{31}$ Articles 8 and 9 of the 2018 Soil Contamination Law.

${ }^{32}$ Article 12 of the 2018 Soil Contamination Law.

${ }^{33}$ Article 22 of the 2018 Soil Contamination Law.

${ }^{34}$ Article 45 of the 2018 Soil Contamination Law.
} 
a result, notwithstanding some encouraging indicators, the reasonableness and effectiveness of the system established by this law will be put to the test in its future implementation. ${ }^{35}$ All in all, the law in parlance is one of the reflections of the construction of EC nationwide in which cultural and moral values (such as protecting soil and preventing pollution) constitute key theoretical and practical components.

\section{APPENDIX}

Figure 1. The timeline of the development of the EC concept in China (above) and of SD globally (below).

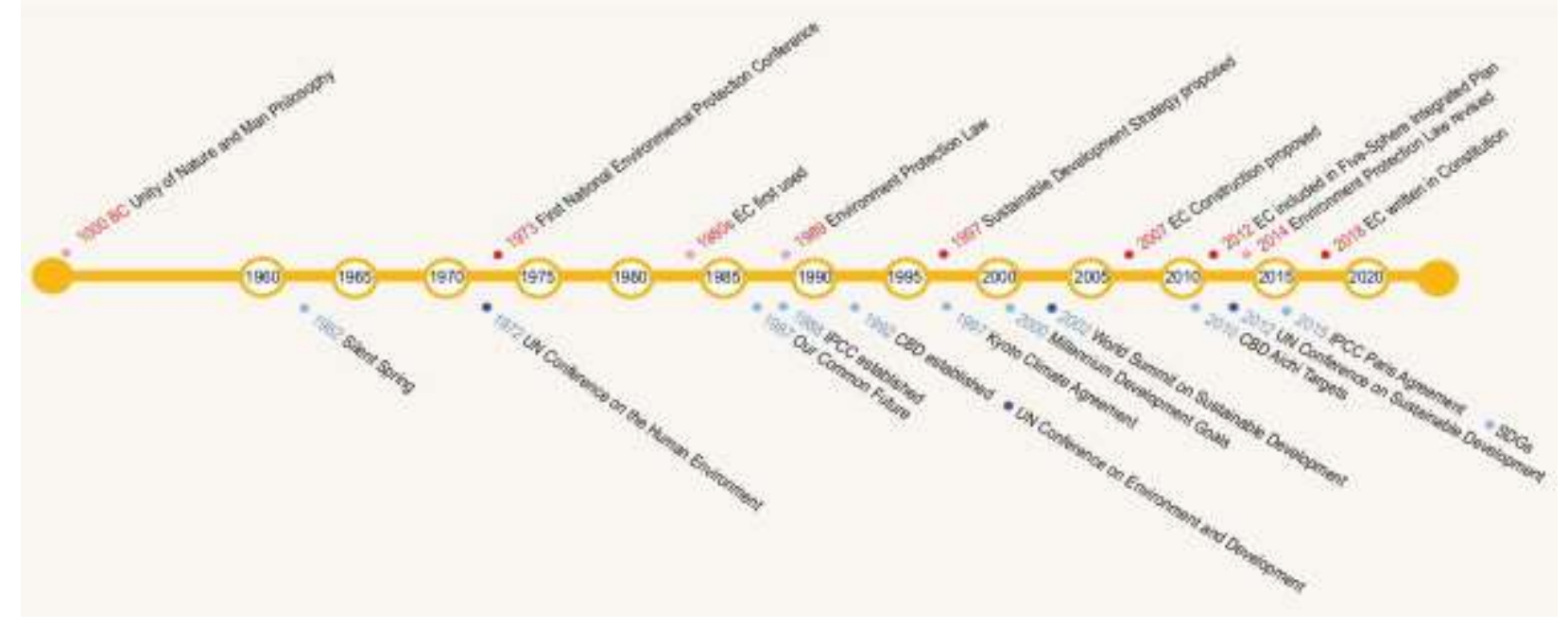

Source: Wei, F., et al. (2020). "Ecological civilization: China's effort to build a shared future for all life on Earth.” National Science Review 8(7). Oxford University Press.

\section{ACKNOWLEDGEMENTS}

The author, a Ph.D. candidate at the Research Institute of Environmental Law - Wuhan University, would like to thank the ESSC (European Society for Soil Conservation), the EURECYS (European Ecocycles Society), and the Organizing Committee for inviting him to the 1st International Joint Congress on "Sustainable Management of Cultural Landscapes in the Context of the European Green Deal," which took place in Santo Stefano di Camastra (Italy) from 10 to 14 November 2021.

\section{-REFERENCES}

Cao, M., Li, H., Sun, D. and Chen, W., 2020. Cancer burden of major cancers in China: A need for sustainable actions. Cancer Communications, 40(5), pp.205-210.

DOI: $10.1002 / \mathrm{cac} 2.12025$

${ }^{35}$ Zhao, X., 2019. Developing an Appropriate Contaminated Land Regime in China. 2nd ed. University of Southern Queensland, Toowoomba, QLD, Australia: Springer.
Cole, M. A., Rayner, A. J. and Bates, J. M. (1997) "The environmental Kuznets curve: an empirical analysis, "Environment and Development Economics. Cambridge University Press, 2(4), pp. 401-416.

DOI: $10.1017 / \mathrm{S} 1355770 \times 97000211$

Goron, C., 2018. Ecological Civilisation and the Political Limits of a Chinese Concept of Sustainability. China Perspectives, 2018(4), pp.39-52.

DOI: $10.4000 /$ chinaperspectives. 8463

Hannam, I., 2022. Soil governance and land degradation neutrality. Soil Security, 6, p.100030.

DOI: $10.1016 /$ j.soisec.2021.100030

Panayotou, T., 2016. 14. Economic Growth and the Environment (pp. 140-148). New York University Press. DOI: $10.18574 / 9781479862689-016$

Stiglitz, J., 2006. Development in defiance of the Washington consensus. [online] Available at:

http://<www.theguardian.com/commentisfree/2006/apr/13/c omment .business [Accessed 20 January 2022]. 
Wang, G., 2014. The State of China's Cities 2014/2015'China Science Center of International Eurasian Academy of Sciences. China Association of Mayors, Urban Planning Society of China and UN-Habitat. Norman Myers, 'China's Approach to Environmental Conservation' (1976) 5 Envtl Aff 33.
Zhang B., Cao, C., Gu, J., and Liu, T., (2016) 'A New Environmental Protection Law, Many Old Problems? Challenges to Environmental Governance in China', 28(2). DOI: $10.1093 / \mathrm{jel} / \mathrm{eqw} 014$

(C) 2022 by the author(s). This article is an open access article distributed under the terms and conditions of the Creative Commons Attribution (CC BY) license (http://creativecommons.org/licenses/by/4.0/). 